\title{
Kan reindriftssamenes bruks- og beiterett giøres mer tjenlig ved bruk av jordskiftelovens virkemidler?
}

\author{
Øyvind Ravna
}

\section{Problemstilling}

Jordskifte er et virkemiddel for å gjøre eiendommer og bruksrettsforhold mer anvendelige. I jordskifteloven (jsk.) $§ 1$ heter det at «Eigedomar som det er vanskeleg å nytte ut på tenleg måte etter tid og tilhøve, kan leggjast under jordskifte etter denne loven». Problemstillingen for denne artikkelen er om jordskiftevirkemidlene kan være anvendelige for å gjøre reindriftssamenes beiteområder mer tjenlige.

Fremstillingen er basert på min doktorgradsavhandling Rettsutgreiing og bruksordning i reindriftsområder som ble forsvart for den juridiske doktorgraden våren $2008 .{ }^{1}$ I doktorgradsarbeidet ble det undersøkt om bruksordning etter jordskiftelovgivningen lar seg gjennomføre i områder der det foregår samisk tamreindrift, under hensyntagen til at de grunnleggende materielle vilkår for jordskifte blir ivaretatt. De grunnleggende materielle vilkår for jordskifte innebærer kort sagt at eiendommer eller bruksrettigheter som er vanskelig å nytte på tjenlig måte, må kunne gjøres tjenlige ved bruk av jordskiftelovens bestemmelser, jf. jskl. $\S \S 1$ og 2, samtidig som ingen part bli påført større tap som følge av dette, jf. jskl. § 3 bokstav a.

Avhandlingens tema har således vært å undersøke om reindriftssamers bruksrettigheter kan gjøres mer tjenlig gjennom bruksordning i medhold av jordskifteloven. Problemstillingen omfattet også bruksordning internt i reindriften, selv om dette

1. Avhandlingen foreligger nå som bok med samme tittel; Rettsutgreiing og bruksordning i reindriftsområder, En undersøkelse med henblikk på bruk av jordskiftelovgivningens virkemidler. Gyldendal, Oslo 2008. Denne artikkelen er basert på forfatterens foredrag på konferansen «Areal og Eiendom» på Ski 25. september 2008 i forbindelse med at han ble tildelt Norges jordskiftekandidatforenings fagpris for 2008. 
ikke er omfattet av gjeldende rett. ${ }^{2}$ At interne forhold i reindriften er unndratt fra bruksordning etter jordskiftelovgivningen, er begrunnet i reindriftens kollektive karakter. Om reindriftsrettens karakter danner slike begrensninger har dermed også vært gjenstand for undersøkelse.

\section{Om anvendelse av jordskiftevirkemidler for} å skape mer tjenlige forhold

\subsection{Anvendelse innen jord- og skogbruk}

Uklare rettsforhold og manglende regler om fordeling av naturressurser i områder som nyttes i fellesskap, kan føre til for store uttak og dermed forringing av ressursene. Historisk sett er det mange eksempler på slike overbeskatninger, både i havet og på landjorda. Helt fra seinmiddelalderen har for store ressursuttak blitt begrenset gjennom fordeling av tilgang til ressursene ved jordskifte eller jordskifteliknende prosesser. Disse har gått ut på å skifte ut ideelle andeler i sameiestrekninger mot individuelle eiendomsparseller, eller å gi bindende regler for bruk basert på den enkeltes andel i sameiet.

På 1700-tallet ble «fellesskap», dvs. jordsameie, omtalt som en av de viktigste årsakene til rovhogst og ødelegging av skogen i deler av Norge. Utskiftning, ${ }^{3}$ hvor hver loddeier fikk en klart definert hogstrett, ble da sett på som en egnet måten å verne om skogen på. ${ }^{4}$

Rovhogst i fellesområder kan sies å være et tidlig utslag av det som senere er omtalt som allmenningens tragedie. Begrepet regnes ofte å være innført av den britiske naturvitenskapsmannen Garrett Hardin i hans mye refererte artikkel «The tragedy of the commons» i Science i 1968 s. 1243-1248, hvor det dras linjer fra felles matsanking i allmenningen til problemer med befolkningsvekst og «freedom to breed». Begrepet var imidlertid velkjent tidligere, bl.a. i debatten om jordeiernes inngjerding av beiteområder i Storbritannia. I dag brukes begrepet i analyser av miljø- og

2. Jeg ser da bort fra bestemmelsen i reinl. $\$ 59$ fjerde ledd, hvor jordskifterettene er gitt funksjonen som «ankeinstans» over reinbeitedistriktenes vedtak om bruksregler.

3. Begrepet utskiftning ble erstattet av jordskifte ved lov av 22. desember 1950 nr. 2 om jordskifte o.a.

4. Se Paul Borgedal, «Jordeiendommenes historie i Norge» i Jordskifteverket gjennom 100 år 1859-1958, Oslo 1959 s. 9-166 særlig s. 143-144. Se også Geir Stenseth, Almenningens janusansikt. En sammenlignende rettslig analyse av almennings- og sameieforhold i norsk utmark, Oslo 2005 s. 318, hvor han med henvisning til Pål Gihle (red.), Forhandlinger om kjøpet av Totenalmenningene. En samling dokumenter 1778-1805, Toten 1974 s. 14, viser at at amtmann Sommerfelt satte forutsetning om «Fellesskabs Ophævelse» da det ga «Skoven bedre og mere ökonomisk Behandling» før kongens allmenning kunne overdras til bøndene. 


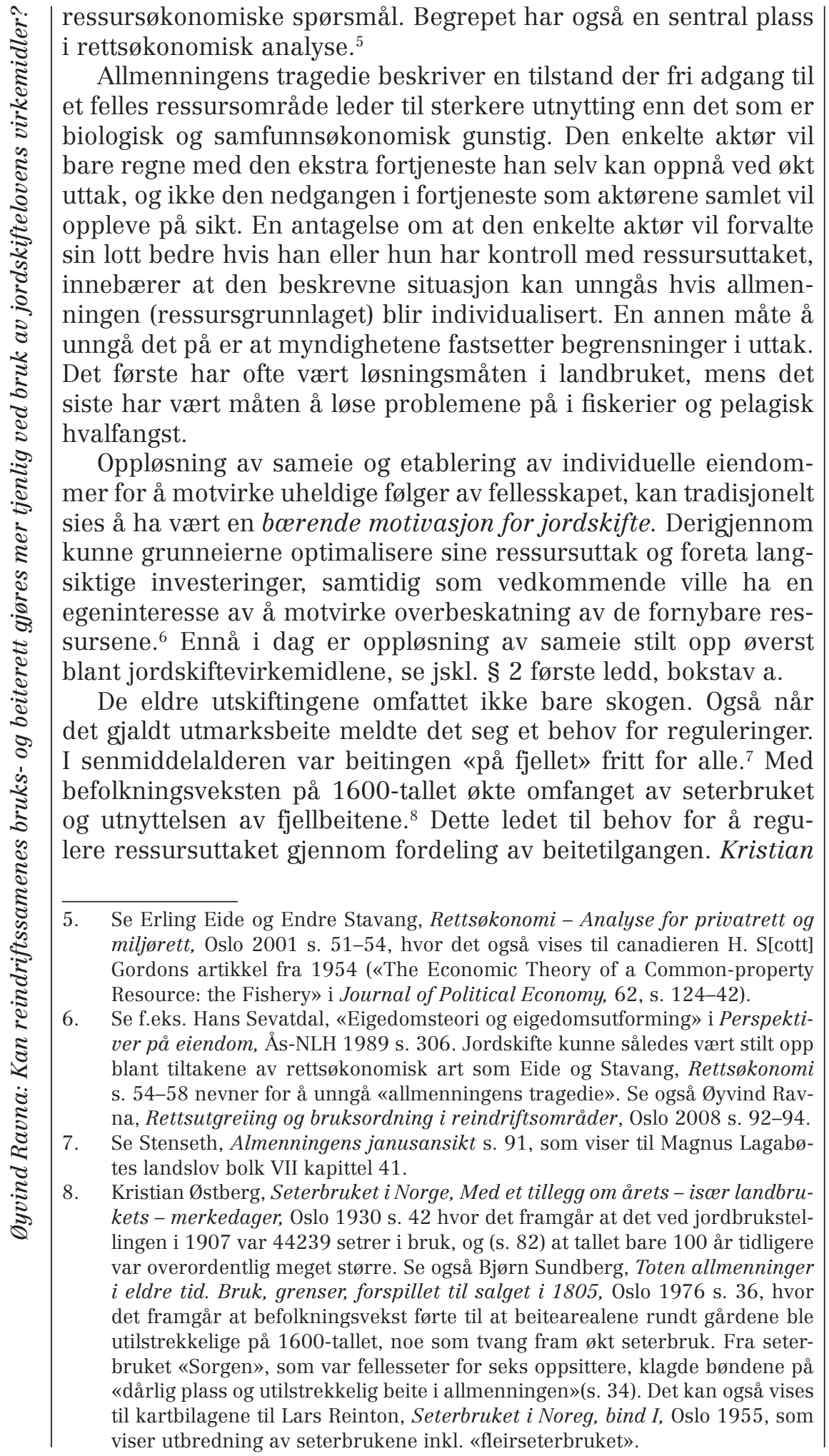


Østberg skildrer på en levende måte hvordan lensmann Per Vean i Aure, og andre lokale «høvdinger» på 1700- og 1800-tallet, i kraft av personlige egenskaper og alminnelig respekt ordnet bruken av så vel innmark og utmark, som den gang lå i henholdsvis teigblanding og sameie. Beitebruken ble organisert med felles gjeting og tidspunkter «hvor længe de kunde beite paa indgjerdet, derefter i bumarken (hjemmehavnen) og saa til seters». ${ }^{9}$

Etter hvert ble slike lokale ordninger avløst av offentlige utskiftninger. På 1800- og 1900-tallet ble en stor del av landets utmarksområder ordnet gjennom utskiftninger. Av praktiske årsaker, bl.a. kostnader til gjerdehold, var det sjelden tjenlig å skifte ut fellesbeiteområder på samme måte som skogen. Selv om sameiet ble beholdt, kunne imidlertid beiteadgangen fordeles gjennom bruksordning, hvor det ble gitt regler for dyretall hver eier kunne føre på beitet med basis i vedkommendes andel i sameiet.

\section{2 «Gammel lære» om reindriftssamers adgang til jordskiftevirkemidler}

For reindriftssamene har det foreligget en «uskreven regel» om at deres bruksrettigheter var av en særegen karakter som falt utenom jordskiftelovenes regler om bruksordning. Det har vært vanlig å oppfatte jordskifterettenes saklige kompetanse slik den ble uttalt av Helge Christensen: «Flyttsamenes rettigheter mht. beite, flyttveier mv. i henhold til reindriftslovgivningen, er av særegen karakter som faller utenfor jordskiftelovenes forskrifter om avløsning og ordning av bruksrettigheter mv.» ${ }^{10}$ Formuleringen ble videreført i kommentarutgaven til Torgeir Austenå og Sverre Øvstedal hvor det het: "Avløysning kan gjennomførast både for reelle og personlege bruksrettar. Dei rettane flyttsamane har til beite m.m. i medhald av reindriftsloven fell utanfor.» ${ }^{11}$

I 1994 ble Austenå og Øvstedals synspunktet brakt videre i annen utgave av Jordskifteloven med kommentarar. Her var det inntatt en henvisning til en artikkel av Jan Endre Aasmundtveit. I artikkelen ble jordskifterettens kompetanse til å behandle reindriftsrettigheter drøftet. ${ }^{12}$ I forhold til avløsning sluttet han seg til oppfatningene til Austenå og Øvstedal, selv om den ble nyansert noe. Videre var hans konklusjon at samiske reindriftsrettigheter ikke var dekket av begrepet «alltidvarande bruksrettar» i jordskifteloven. ${ }^{13}$

9. Kristian Østberg, Norsk bonderet, femte bind, sedvaner i granneforhold, Oslo 1928 s. 24-27.

10. Helge Christensen, Jordskifteloven med kommentar, 2. utg., Oslo 1962 s. 123.

11. Torgeir Austenå og Sverre Øvstedal, Jordskifteloven med kommentarar, Oslo 1984 s. 150.

12. Jan Endre Aasmundtveit, «Jordskifte og reindriftsrettigheter» i Kart og Plan 1991 s. 263-268.

13. Nærmere om dette i Øyvind Ravna, Rettsutgreiing og bruksordning i reindriftsområder, Oslo 2008 s. 185-187. 


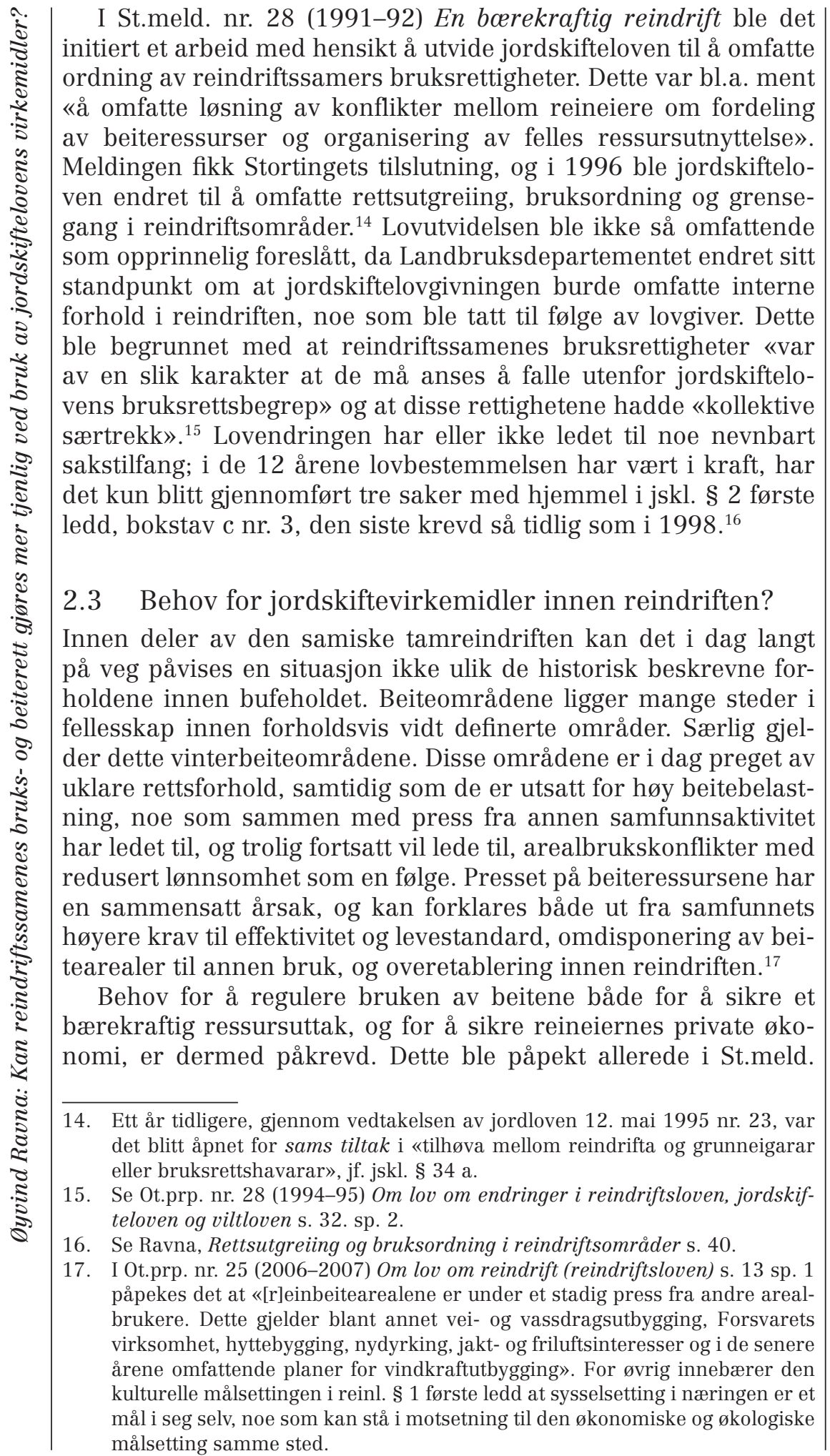


nr. 28 (1991-92). Behovet er ikke blitt mindre de seneste årene, noe bl.a. Riksrevisjonens undersøkelse av reinbeiteressursene i Finnmark og Ot.prp. nr. 99 (2004-2005) om lov om endringer i lov 9. juni 1978 nr. 49 om reindrift, må sies å understreke.

I Dokument nr. 3:12 (2003-2004) Riksrevisjonens undersøkelse av bœrekraftig bruk av reinbeiteressursene $i$ Finnmark s. 2 sp. 1 uttales det at «det ikke i tilstrekkelig grad foreligger rammebetingelser i form av øvre reintall [...] soneinndelinger, beitetider, etableringskontroll og distriktsplaner som forutsatt i reindriftsloven. Å fastsette rammebetingelser som gir forutsigbarhet for reindriftsutøverne, er viktig for en økologisk bærekraftig utnyttelse av beiteressursene». Av St.prp. nr. 74 (2006-2007) s. 16-17 framgår det at reindriftsforvaltningen sluttet seg til Riksrevisjonens situasjonsbeskrivelse og har vedtatt retningslinjer for å fastsette rammebetingelser. Den vanskelige ressursmessige situasjonen for reindriften i deler av Finnmark ledet til at Landbruks- og matdepartementet gikk til det skritt å fremme Reindriftslovutvalgets sanksjonskapittel, hvor det ble foreslått tvangstiltak som om nødvendig kunne innebære tvangsslakting, i en egen lovproposisjon, Ot.prp. nr. 99 (2004-2005). Departementet begrunnet dette med at «muligheten for reintallstilpasning gjennom økonomiske stimuleringstiltak nå i all hovedsak anses uttømt». Dette krevde etter departementets syn «en rask oppfølging med utgangspunkt i reindriftslovens bestemmelser». Forslaget ledet ikke til lovvedtak i 2005, men er i all hovedsak vedtatt i kapittel 11 i gjeldende reindriftslov som trådte i kraft 1. juli 2007.

Samtidig har rettsutviklingen gått i retning av en aksept av at reindriftssamenes bruksrettigheter er av privatrettslig karakter, etablert gjennom sedvane og alders tids bruk, se f.eks. Selbudommen i Rt. 2001 s. 769 og gjeldende reindriftslov (15. juni 2007 nr. 40) $\$ 4$ første ledd. Reglene om bruksregler i samme lov kapittel 7 understreker dette. ${ }^{18}$ Det kan også vises til at Landbruks- og matdepartementet beskriver økt oppmerksomhet på bruksrettigheters omfang som et problem når siidagrenser skal fastsettes, noe som bl.a. har medført at det ikke har vært den forventede progresjon for å inngå frivillige avtaler om beitebruk. Tiltak «for å få nødvendig rettslig avklaring [vil derfor] stå sentralt». ${ }^{19}$

Avklaring av rettsforhold og ordning av beitebruk vil her kunne være et bidrag både til bedre ressursforvaltning og optimalisering av privat inntekt. Dette er erkjent og påpekt av Det nasjonale reindriftsstyret, som også har etterlyst en instans som kan

18. Se også Reindriftsforvaltningen, Ressursregnskap for reindriftsnæeringen for reindriftsåret 1. april 2005-31. mars 2006, Alta 2007 s. 2, hvor Reindriftsforvaltningen erkjenner at «reindriftsretten har vært gjenstand for relativt store endringer i de seinere år. Sedvane og alders tids bruk har nå fått en sentral plass i reindriftsretten».

19. St.prp. nr. 74 (2006-2007) Om reindriftsavtalen 2007/2008, om dekning av kostnader vedrørende radioaktivitet $i$ reinkjøtt, og om endringer $i$ statsbudsjettet for 2007 m.m. s. 17 sp. 1. 
avklare rettsforhold og fastsette siidaenes områder. ${ }^{20}$ Også i rettsøkonomisk teori er dette påpekt, hvor nettopp reinbeite er nyttet som eksempel på en ressurs hvor overutnyttelse ville vært unngått «[m]ed veldefinerte eierrettigheter». ${ }^{21}$

At reindriftssamene kan ha bruksrettigheter av privatrettslig karakter tilsier at regulering og fordeling av beiteadgang må skje under hensyntagen til at enkeltpartenes etablerte rettigheter ikke blir krenket. Et av de grunnleggende materielle vilkårene for jordskifte er nettopp at ingen part kan bli påført større kostnad og ulempe enn nytte ved regulering og omforming av eiendoms- og bruksrettigheter. Regler om fordeling basert på et fastsatt skiftegrunnlag, jf. jskl. $§ \S 27$ og 28, med et skifteregnskap som må være i balanse før og etter ordningen, danner grunnlag for en del av prøvingen av dette vilkåret. At saken ikke medfører kostnader av annen art, f.eks. økte driftskostnader, som overstiger nytten av saken for den enkelte part, utgjør den øvrige delen av denne prøvingen.

Gjennomgangen viser således at det er behov for å ordne beitebruken, og at bruk av jordskiftevirkemidler kan være en vei å gå for å forestå dette.

\section{Gjeldende lovgivning om jordskifte $\mathrm{i}$ reindriftsområder}

\subsection{Hva omfatter gjeldende lovgivning}

Ved endringslov nr. 8/1996 ble det inntatt ny nr. 3 i hjemmelen for bruksordning i jskl. $\$ 2$ første ledd bokstav c, som sa at «[j]ordskifte kan gå ut på å [...] gi reglar om bruken i det samiske reinbeiteområde der det foregår reindrift etter lov 9. juni 1978 nr. 49 om reindrift $§ 2 » .^{22}$ I annet punktum ble det tatt forbehold om at jordskifteretten «ikkje kan regulere tilhøva mellom dei som utøver slik reindrift». Adgangen til å kreve slik sak, ble foruten de som har kravkompetanse etter jskl. $§ 5$ første ledd, lagt til «leiar av reinbeitedistrikt», jf. samme paragraf, tiende ledd.

20. Reindriftsforvaltningens arkiv: Møtebok for Reindriftsstyret sak nr. 17/2004, Alta 29. juni 2004 s. 23. Her ble det vist til at man i jordbruket har jordskifteretten som tar seg av tilsvarende spørsmål: «Slik Reindriftssjefen ser det så er det et like stort behov for et organ som kan håndtere slik[e] spørsmål innen reindriften som det er innen jordbruket.» Reindriftssjefen er leder av den nasjonale fagmyndigheten for reindriften.

21. Eide og Stavang, Rettsøkonomi s. 52. I denne sammenheng vil også «veldefinerte» bruksrettigheter fylle samme funksjon. Sml. også op.cit. s. 58.

22. Ved ikrafttreden av gjeldende reindriftslov 1. juli 2007 ble «etter lov 9. juni 1978 nr. 49 om reindrift» fjernet både i jskl. § 2 første ledd bokstav c nr. 3 og jskl. § 35 i) uten at noe kom i stedet. Dette var ikke ment å være noen realitetsendring, men en endring av terminologisk art, se Ot.prp. nr. 25 (2006-2007) s. 73 sp. 2. 
Gjennom samme endringslov fikk jskl. § 35 også en ny bokstav i), hvor det heter at «[r]egler om bruk og sambruk kan mellom anna gå ut på ... ordne tilhøva mellom reindrifta og grunneigarar og andre rettshavarar i område der det går føre seg reindrift ... når det gjeld beite, flyttelei og liknande». Paragraf 35 gir ikke noen selvstendig hjemmel for bruksordning, men angir former for bruksordning som er særlig aktuelle. ${ }^{23}$

Hva kan så regelen om bruksordning i områder hvor det foregår reindrift omfatte? For ordens skyld kan vi først slå fast at det nevnte forbeholdet i jskl. $\S 2$ første ledd bokstav c nr. 3 annet punktum om at jordskifteretten ikke kan regulere forholdene mellom de som utøver reindrift, er en positiv begrensning som utelukker at reindriftssamer kan kreve at jordskifterettens virkemidler blir brukt for å ordne beite- og arealbruk internt i reindriften. At reineierne ikke har individuelle rettigheter til beite er brukt som begrunnelse for dette. Slike saker «skal behandles av de forvaltningsorganer som er opprettet for dette formål, eventuelt av de ordinære domstoler». ${ }^{24}$ Denne begrensningen må sies å være absolutt og stenger således for analyse av om jordskifteretten har noen saklig kompetanse til å holde bruksordning internt i reindriften etter gjeldende rett. ${ }^{25}$

Som vi har sett var det opprinnelig ikke tiltenkt inntatt slike begrensninger i lovgivningen. ${ }^{26}$ Da Landbruksdepartementet la fram Ot.prp. nr. 28 (1994-95) var imidlertid ambisjonen om at jordskifterettene skulle ordne beitebruk og løse konflikter internt i reindriften, lagt bort. I det følgende skal vi kort se på hvilken veiledning lovproposisjonen gir for de bruksordningsreglene som i dag er gjeldende rett. I tilknytning til merknadene til jskl. § 2 pekes det på at bruksordning mellom bufeholdere og reineiere vil innebære at jordskifteretten må «gjøre det klart hvilke rettsforhold som gjelder». Selve bruksordningen kan gå ut på 1) «å fastsette øvre grense for hvor mange beitedyr det kan være i et område», 2) «foreta avgrensning av beitesesong», 3) «legge ned forbud mot bruk av visse områder», eller 4) «fastsette særskilte beiteområder for henholdsvis sau og rein». ${ }^{27}$ Under merknaden til jskl. $\$ 35$ pekes det på at bruksordning av «reindriftsproblematikken» foruten ordning av beite også kan omfatte regulering

23. Slik Austenå og Øvstedal, Jordskifteloven s. 201.

24. Ot.prp. nr. 28 (1994-95) s. 55.

25. Sml. dog jskl. § 17 første ledd, som pålegger jordskifteretten å ta standpunkt til de tvister som er nødvendig å løse av omsyn til jordskiftet. For øvrig ser jeg her bort fra den saklige kompetanse jordskifterettene har som «ankeinstans» over distriktsstyrenes vedtak, jf. reinl. § 59 fjerde ledd. Rekkevidden av sistnevnte bestemmelse er behandlet i Ravna, Rettsutgreiing og bruksordning $i$ reindriftsområder $\mathrm{s}$. 297-306.

26. Se St.meld. nr. 28 (1991-92) særlig på s. 109.

27. Ot.prp. nr. 28 (1994-95) s. 55 sp. 2. Dette gjenfinnes også hos Austenå og Øvstedal, Jordskifteloven s. 38 og i Jordskifteverket, Reindrift og jordskifte (uten år [1996]), uten ytterligere utdyping. 
av flyttleier, adgang til å anlegge slakteplass mv.: «Med andre ord er det forhold som omtales i reindriftsloven [av 1978] § 9 om hva reindriftsretten omfatter, som kan være gjenstand for bruksordningen. ${ }^{28}$

Hvis vi ser på de enkelte punktene, så er det første, å «gjøre det klart hvilke rettsforhold som gjelder», en forutsetning for ethvert jordskifte, jf. jskl. § 16 annet ledd. А fastsette «øvre grense for hvor mange beitedyr det kan være i et område» (for hver part) er en tradisjonell bruksordningstype, hvor partene får fordelt beiteadgang med bakgrunn i sitt skifte- eller delingsgrunnlag. Det er for øvrig også avgrensning av beitesesong, nedlegging av forbud mot bruk av visse områder og fastsetting av særskilte beiteområder for henholdsvis sau og rein. Disse bestemmelsene synes dels å være inspirert av andre punkter i jskl. § 35, og dels av bygdeallmenningsloven $\S 6-3$, hvor allmenningsstyret kan fastsette beiteordninger. Samtidig må det sies at begrunnelsen i proposisjonen kan gi inntrykk av å være utformet med en intensjon om å begrense reindriftsutøvernes ressurstilgang, heller enn å skape mer tjenlige forhold innen næringen.

En vurdering av om de grunnleggende vilkårene for jordskifte rent faktisk kan prøves ved ordning av reindriftsområder synes i mindre grad å være vektlagt. Det er etter mitt skjønn en vesentlig mangel ved lovgivningen. ${ }^{29}$

\subsection{En vurdering av gjeldende rett}

Undersøkelsen av gjeldende lovgivning har vist at lovendringen som ble vedtatt i 1996, og som åpnet for ordning av beitebruk mellom reindriftsutøvere og andre rettshavere, ikke innehar regler som i tilstrekkelig grad gir reindriftsutøvere samme forutsigbarhet ved gjennomføring av slike bruksordninger som det grunneiere og andre bruksrettshavere kan forvente. Det skyldes bl.a. at det ikke er tatt stilling til hvordan de grunnleggende materielle vilkår for jordskifte skal kunne prøves. ${ }^{30}$ Det innebærer igjen at bestemmelsen i jskl. § 3 bokstav a, om at jordskifte ikke kan fremmes hvis kostnadene og ulempene blir større enn nytten for den enkelte part, og som er den enkeltes garanti mot å bli påført tap ved jordskifte, vanskelig kan prøves med nødvendig presisjon. I realiteten kan dette innebære at reineiere blir påført et inngrep i sine bruks- og beiterettigheter som kan være i strid både med Grunnloven § 105 og Den europeiske menneskerettskonvensjon protokoll 1 artikkel 1.

28. Ot.prp. nr. 28 (1994-95) s. 59 sp. 2. Reindriftsloven av 1978 § omtalte følgende «forhold»: 1. rett til opphold med rein og til ferdsel, flytting og flyttleier. 2. rett til beite for rein, 3. rett til anbringelse av anlegg som trengs til reindriften, 4. rett til brensel og trevirke, 5. rett til jakt, fangst og fiske.

29. Dette er nærmere begrunnet i Ravna, Rettsutgreiing og bruksordning i reindriftsområder, s. 243-297.

30. Op.cit. s. 254-263 og 310-314

304 
Lovgivers forutsetning om at reindriftsretten er av en kollektiv karakter, som «tilligger samene som folkegruppe», har ledet til at rettssubjektet for bruksordning er reinbeitedistriktet, og ikke siidaen (driftsgruppa) eller den enkelte reindriftsutøver. Dette skaper vansker i relasjon til jordskifte etter gjeldende rett, da det gjør hele distriktet til part selv om saken kun angår en siida. At «ikketapsgarantien» etter jskl. § 3 a skal prøves mot reinbeitedistriktet, og ikke siidaen eller den enkelte part, ${ }^{31}$ kan i praksis innebære at enkeltparter kan bli påført tap ved en skjev fordeling innad i distriktet. Dette kan ikke sies å være i samsvar med jskl. § 3 bokstav a.

Gjennomgangen av gjeldende regler om bruksordning i reindriftsområder viser videre at jordskifteretten vil støte på flere problemer når ordningene skal gjennomføres. Det kan her pekes på at rettshaverne har svært forskjellig rettsgrunnlag, noe som kan skape problemer når skiftegrunnlaget som skal fordele beiteadgang mellom reineiere og bufeholdere skal fastsettes. Hvordan fastsette en omregningsfaktor mellom reindriftssamers og bufeholderes rettsstørrelse/skiftegrunnlag, slik at disse kan veies mot hverandre, er heller ikke drøftet.

Noen av de problemene som her er påpekt, kan i praksis løses gjennom godt dommerskjønn. Rettsuklarhet (rettstvister) mellom reineiere og bufeholdere kan avklares etter de forholdsvis tradisjonelle tingsrettslige læresetninger om alders tids bruk, hvis man tar høyde for de normene Høyesterett har fastlagt gjennom Selbudommen i Rt. 2001 s. 769. Selv om lovgiver ikke har gitt veiledning om det, kan skiftegrunnlaget fastsettes med utgangspunkt i bufeholders og reineiers etablerte bruk over tid, fortrinnsvis uttrykt i beitedyr for den enkelte dyreholder.

Fastsetting av omregningsfaktor for beiteforbruk hos rein og bufe, som er en forutsetning for å kunne fordele beiteadgang mellom partene der det foregår fellesbeiting, synes imidlertid vanskelig å løse i praksis, uten at det framskaffes mer biologisk kunnskap om dette. Om slike saker likevel fremmes til behandling, bør det presumeres at forholdstallet mellom rein og sau er 1:1.32

Både usikkerheten omkring de biologiske faktorene, og at lovgiver ikke har gitt veiledning om hvordan de grunnleggende materielle vilkårene for jordskifte skal prøves, innebærer fravær av tilstrekkelig forutsigbarheten for de ordninger som kan bli vedtatt. Følgene av de manglende lovgivningen har på dette området blitt at spørsmålene om hvordan de grunnleggende materielle vilkår for jordskifte skal prøves overlates til den enkelte jordskifterett. Dette innebærer at disse ikke bare må ta stilling til hvor grensene for reindriftsrettigheter skal fastsettes, så vel som omfanget av rettighetene, men også hvilke prinsipper som skal legges til grunn

31. Slik Ot.prp. nr. 28 (1994-95) s. 55 sp. 2.

32. Se Ravna, Rettsutgreiing og bruksordning i reindriftsområder s. 281-283 og s. 296. 
for dette. Dette er ikke i samsvar med lovgivning og praksis for andre typer jordskiftesaker.

\section{Bruksordning internt i reindriften}

4.1 Hvorfor har ikke reindriftsutøvere hatt adgang til jordskiftevirkemidlene?

I punkt 2.2 så vi at reindriftssamers bruksrettigheter er blitt betraktet å være av en saregen karakter som falt utenom jordskiftelovens virkeområde, slik det ble uttrykt av Christensen i hans kommentar til jordskifteloven fra 1962, og slik det ble lagt til grunn av lovgiver i 1996. En gjennomgang av rettsutviklingen gir ikke noen direkte forklaring på hvorfor oppfatningen har vært slik. Det er imidlertid ikke usannsynlig at dette kan ses i sammenheng med den rådende oppfatningen på midten av 1900-tallet om at reindriftsretten var en «uskyldig nyttesrett» eller en slags «allemannsrett» for samer som ikke kunne være rettsdannende. ${ }^{33}$.

Rettsutviklingen synes derimot langt på veg å forklare hvorfor reindriftssamenes bruksrettigheter er blitt betraktet som kollektive, tilliggende samene som etnisk gruppe, og ikke som tinglige rettigheter for den enkelte reindriftsutøver eller siida. Denne oppfatningen kan spores helt tilbake til forarbeidene til reindriftsloven av 1933, som hadde sine røtter i lappekommisjonene oppnevnt på slutten av 1800-tallet. Selv om oppfatningen av reindriftsretten som en «uskyldig nyttesrett» ble satt til side med Brekken- og Altevann II-dommene i 1968, ble oppfatningen av reindriftsretten som en kollektiv rett uten noe definerbart rettssubjekt, videreført og forsterket gjennom Kappfjell-dommen i Rt. 1975 s. 1029. Til tross for at reineierne i Kappfjell, Røssåga og Brurskanken reinbeitedistrikter m.fl. ble tilkjent erstatning, ble dommen et prejudikat for at det er «samenes reindrift som næring» (s. 1033) som nyter rettsvern, og at det er «flyttsamene som etnisk gruppe som er bærere av denne rett» (annenvoterende, s. 1035). Dommen ble tillagt stor vekt da Landbruksdepartementet skrev proposisjonen til endring av reindriftsloven og jordskifteloven i 1994-95. Dette medvirket nok igjen til at det ikke ble åpnet for at bruksordning kunne holdes internt i reindriften da lovreglene om reindrift og jordskifte ble vedtatt i 1996.

Den oppfatning som ble uttrykt i Kappfjell-dommen, og som medvirket til at rettssubjektet til reindriftsretten ble «flyttsamene som etnisk gruppe», hadde ikke støtte i sedvanemessige oppfatninger hos reindriftssamer, slik disse er beskrevet av Erik Solem i 1933. Tross høyesterettsdommen fra 1975 og de senere lovendringene har oppfatningen heller ikke fått støtte i de seneste

33. Op.cit. s. 331-355. Som en særlig kuriositet kan det vises til s. 352-353, hvor det framgår at reindrift utøvd av ikke-samer ble vektlagt når Høyesterett tilkjente privat eiendomsrett til fjellområder i Sør-Norge. 
undersøkelsene av samiske sedvaner og rettsoppfatninger, utført for Samerettsutvalget og trykt i NOU 2001: 34. Nyere rettspraksis har da også satt oppfatningen i Kappfjell-dommen til side. Det kan her vises til Seiland-dommen i Rt. 2000 s. 1578. Sedvanerettsundersøkelsen jeg utførte sammen med Jan Olli viser også at det er siidaen eller den enkelte reindriftsutøver som anses som rettsbærer til reinbeiteområdene. ${ }^{34}$ Gjennom vedtakelsen av reindriftsloven av 2007 har også lovgiver erkjent siidaens rolle som sosial og organisatorisk overbygning for reindriftsutøvere, og som rettssubjekt til den reindriftsrett som hviler på bestemte arealer.

Rettsutviklingen viser således at det ikke er en «naturgitt» forutsetning som sier at reindriftsrettens kollektive karakter danner skranker for bruksordning internt i reindriften etter vilkår for jordskifte. Det avgjørende for om en bruksrett i denne sammenheng kan være gjenstand for jordskifte, er ikke om den er av «kollektiv karakter», men om gruppens medlemmer; rettssubjektet, utgjør en bestemt krets med rettigheter knyttet til bestemte arealer. Det gjør reindriftssiidaen. ${ }^{35}$ Det er dermed ikke grunnlag for å hevde at reindriftsretten har «et utpreget kollektivt særtrekk» som er et hinder for bruksordning etter vilkår for jordskifte.

At det må tas hensyn til reindriftens egenart og kultur i slike saker, er derimot ganske opplagt. Dette kan bl.a. skje ved at beiteordningsreglene innen reindriften gjøres noe mer fleksible og reversible enn reglene for saker hvor fordeling av naturressurser gjennom lang tid har vært basert på privat eiendomsrett. Dette kan gjøres ved å åpne for at retts- og skiftegrunnlaget kan fastsettes på nytt ved en eventuell senere bruksordning.

En samlet gjennomgang av rettskildene viser således at det kan reises spørsmål ved om det standpunkt lovgiver tok i 1996, og som begrunner gjeldende lovgivning om reindriftssamers adgang til å være part i jordskifte, var basert på korrekt rettsoppfatning i samtiden. Begrunnelsen om at reindriftsretten var av en kollektiv karakter som falt utenfor jordskiftelovens bruksrettsbegrep, synes langt på veg heller å ha vært en måte å begrunne nødvendigheten av å gjennomføre et påstartet lovarbeid etter at departementet hadde endret sitt standpunkt. Den tvil som eventuelt måtte foreligge om gjeldende rett på 1990-tallet, er satt til side av de seneste årenes rettsutvikling. Med Landbruks- og matdepartementets uttalelse om at det ikke foreligger tungtveiende innvendinger mot at jordskifteretten også får oppgaver knyttet til interne forhold i reindriften

34. Olli, Jan og Øyvind Ravna, Sedvanerettslige oppfatninger om arealbruk blant reindriftsutøvere. Herunder oppfatninger om reintallsfastsetting og om jordskiftevirkemidler er egnet for å ordne beitebruk i reindriftsområder, upublisert, 2007.

35. Nærmere om dette i Øyvind Ravna, «Reindriftssamenes bruksretter og jordskifterettens saklige kompetanse» i Tidsskrift for Rettsvitenskap, vol. 120, $1-2 / 2007$ s. $220-251$. 
i Ot.prp. nr. 25 (2006-2007), og vedtagelsen av ny reindriftslov, burde spørsmålet under alle omstendigheter være avklart

\subsection{Hvordan gjennomføre bruksordning internt i} reindriften?

I ordning av bruk mellom reindriftsutøvere vil ikke problemene knyttet til forskjellig rettsgrunnlag og varierende beiteforbruk være til stede. Det vil således være enklere å fastsette et ens skiftegrunnlag og vurdere om en part blir påført større kostnad enn nytte i slike saker. Dette innebærer at ordning av beitebruk o.a. mellom de som utøver reindrift ikke reiser like store problemer i relasjon til å kunne prøve de grunnleggende materielle vilkårene for jordskifte, som saker mellom reineiere og bufeholdere..

De uavklarte rettsforholdene i deler av det samiske reinbeiteområdet skaper imidlertid også utfordringer ved bruksordning. Vurderingen av den gode tro eller av rettsutøverens hjemmel for bruk reiser problemer når rettserverv etter reglene for hevd og alders tids bruk skal prøves. Det bør innebære en viss forsiktighet i anvendelsen av reglene og at det kanskje bør siktes mot en kvalitativ rettsfastsetting for å komme fram til et skifte- eller fordelingsgrunnlag mellom reindriftspartene, framfor en rettsavklaring som leder til at det blir dratt opp faste grenser mellom siidaene. Dette arbeidet bør innbefatte forhandlinger og meklinger hvor partene får delta aktivt.

Økt tjenlighet i reindriftssammenheng kan alene bestå i avklarte rettsforhold. Skal det forsvares at dette skjer utenom de alminnelige domstolene, bør det være behov for mer enn bare rettsavklaring. Fastsetting av skifte- eller delingsgrunnlag for de enkelte siidaandelene og siidaene med bakgrunn i deres rettsstørrelse, for å bidra til å fordele beiteadgang o.a., kan være et slikt tiltak. For reineiere er den eneste målbare størrelsen for rettsomfanget det antall dyr de har ført på beite. For at etablert bruk, og ikke tilfeldigheter eller posisjoneringer, skal være avgjørende, må reintallet ses over tid, f.eks. over 10 eller 20 år, når et slikt skiftegrunnlag fastsettes. ${ }^{36}$ Dette grunnlaget kan nyttes for å regulere beiteadgang gjennom fastsetting av reintall innad i siidaen og mellom siidaer der det foregår sambruk. Skifte- eller delingsgrunnlaget kan også nyttes for å fastsette beitetider eller særskilte områder for siidaene, til å fordele kostnadene ved investeringer som gjerdehold og vegbygging, og til å fordele arbeidsbidrag for å unngå «gratispassasjerproblematikken».

I denne sammenheng kan det være nyttig å minne om at Landbruksdepartementet i forarbeidet til gjeldende jordskiftelov, Ot.prp. nr. 56 (1978-79), foreslo at bruksordning (for jordbrukere) kun kunne gå ut på å fastsette delingsgrunnlaget når et

36. Motsatt reinl. $§ 60$ tredje ledd, hvor det skal tas utgangspunkt i aktuelt reintall når reintallsreduksjon skal gjennomføres forholdsmessig. 
bestemt bruksformål var fastlagt. Dette fordi bøndene selv ville ha vansker med å fastsette et delingsgrunnlag, noe som kunne skape vansker for frivillig samarbeid og for å få til flertallsvedtak. Departementet uttalte også «at samfunnet har plikt til å hjelpe slik at eigarane sjølve på ein betre og sikrare måte kan ta vare på og utnytte ressursane sine utan anna hjelp frå jordskifterettane enn den dei sjølve ønskar og treng». Etter mitt skjønn burde det samme kunne anføres her; samfunnet har plikt til å hjelpe reineierne slik at de på en bedre måte selv kan fordele og utnytte sine ressurser. Fastsetting av delingsgrunnlag innen reindriften kan da være en god start.

\section{Konklusjon/oppsummering}

Gjennomgangen viser at gjeldende jordskiftelovgivning ikke er velegnet for å ordne beitebruk i reindriftsområder. Når lovgiver ikke har maktet å gi regler om hvordan de grunnleggende vilkår for jordskifte skal prøves, herunder hvordan skiftegrunnlag skal fastsettes, har lovverket på dette området så vesentlige mangler at det etter mitt skjønn burde ha ledet til større forsiktighet da bestemmelsene om jordskifte og reindrift ble vedtatt.

Undersøkelsen i mitt avhandlingsarbeid må imidlertid sies å vise at bruksordning hvor de grunnleggende materielle vilkårene for jordskifte blir hensyntatt, kan være et egnet virkemiddel for å skape mer tjenlige forhold i reindriftsområder. Dette gjelder særlig der det er behov for å avklare og ordne beitebruksforhold mellom de som driver reindrift, altså internt i reindriften. Men dette krever en innsats fra lovgiver, som bl.a. må initiere utredning av så vel juridiske som økonomiske og kulturelle sider av slike ordninger. På den måten kan også det samiske samfunn kan ta igjen noe av den eiendomsrettslige utviklingen det har mistet som følge av at det ikke er blitt tilkjent eierrådigheten til sine produksjonsarealer på samme måte som aktørene i det norske bondesamfunnet. Dessuten kreves det også forskning av biologisk art for å vurdere beiteadferd og beiteopptaksforhold mellom rein og sau, hvis ordningen skal omfatte forhold mellom jordbrukere og reineiere.

Det kan anføres argumenter både for og imot bruk av jordskiftevirkemidler, som er ordninger basert på at den enkeltes private rettsstørrelse danner grunnlag for fordeling av felles beiteressurser. Et hovedspørsmål er om det er ønskelig med fastere rammer om reindriften, noe bruksordning etter vilkår for jordskifte vil lede til. Eller skal det fortsatt være rom for den fleksibilitet og foranderlighet som har ligget forankret i reindriften? Svaret ligger kanskje i et kompromiss, hvor ikke altfor inngripende bruksordninger med reversible rammer kan være løsningen. Av vesentlig betydning er også de faglige forutsetningene for de instanser som skal utføre bruksordning i reindriftsområder. I forarbeidene til den nylig vedtatte reindriftsloven har Landbruks- og matdepar- 
tementet gått inn for det bygges opp reindriftsfaglig kompetanse ved to jordskifteretter slik at de kan fungere som «reindriftsdomstoler». Etter mitt skjønn er dette et godt forslag som bør følges opp. ${ }^{37}$ Dette innbefatter også at det må ses på rekrutteringen og utdanningen av de som i framtiden skal bli «reindriftsdommere». Om det skal gis regler som er mer hensiktsmessige enn dagens, må i siste instans avgjøres av våre politikere gjennom Stortinget som lovgiver. Når det eventuelt skjer, bør så vel det samiske folks stemme som reindriftsutøvernes egne organisasjoner tas med i grundige konsultasjoner.

Som nevnt kan det reises spørsmål ved om det standpunkt lovgiver tok i 1996, og som begrunner gjeldende lovgivning om reindriftssamers adgang til å være part i jordskifte, var basert på korrekt rettsanalyse i samtiden. Med Landbruks- og matdepartementets erkjennelse i forarbeidene til ny reindriftslov om at det ikke foreligger tungtveiende innvendinger mot at jordskifteretten også får oppgaver knyttet til interne forhold i reindriften, samt vedtagelsen av samme lov 15. juni 2007, er standpunktet fra 1996 under alle omstendigheter rettslig sett foreldet. Erkjennelsen har imidlertid ikke ledet til endringer i jordskifteloven med henblikk på reindriftsutøvers adgang til å kreve bruksordning. Det har så langt heller ikke ledet til at den arbeidsgruppa Landbruks- og matdepartementet har nedsatt for å utrede en jordskiftelovrevisjon har fremmet forslag om endringer. Hvis det forslag som så langt er framsatt blir lagt til grunn, ${ }^{38}$ vil det heller ikke denne gang bli åpnet for at samiske reindriftsutøvere skal kunne velge om de skal kunne nytte de samme virkemidler som norske bufeholdere for å få lagt til rette for mer tjenlige beiteforhold.

Dette vil etter mitt syn være uheldig, og det vil i den sammenheng kunne reises spørsmål om likebehandling og om Norge oppfyller sider av sine folkerettslige forpliktelser overfor denne del av den samiske befolkningen. At den norske stat er grunnlagt på to folks territorier, og at reindrift er en like framtidsrettet og, $\mathrm{i}$ sine områder, like viktig næring for landet som jordbruket, tilsier at lovgivningen bør harmoniseres slik at reindriftssamer selv kan velge om de vil ha bistand fra en utenforliggende instans når rettsuvisse skal avklares og beitebruk ordnes. Gjennom den pågående jordskiftelovrevisjonen har lovgiver nå en gyllen anledning til å sørge for dette.

37. Se Ravna, Bruksordning og Rettsutgreiing i reindriftsområder s. 512-523.

38. I utkast til lov (av 25.02.08) § 3-13 fjerde ledd (som erstatter jskl. § 2 bokstav c nr. 3) heter det: I område der det går føre seg reindrift etter reindriftslova, kan jordskifteretten regulere tilhøva mellom reindrifta og andre rettshavarar, se http://www.regjeringen.no/nb/dep/lmd/Tema/andre/Jordskifte/jordskiftelovrevisjonen.html (sist besøkt 01.10.08). I notat nr. 3 frå arbeidsgruppa til referansegruppa, versjon 3, 14.03 .07 s. 34 (samme referanse) er dette begrunnet slik: «Erfaringa med saker etter denne heimelen tilseier at ein ikkje treng å gjøre endringar.» Se for øvrig Ravna, Bruksordning og Rettsutgreiing $i$ reindriftsområder $\mathrm{s} .318$ og s. 389. 